\title{
Croscarmellose Sodium Efficiency in the Development of a Generic Capsule Formulation of Piroxicam, Comparable Dissolution Profile to the Innovator Product, Feldene
}

\author{
Nwoko Valentine E \\ Formulation Pharmacist, Phamatex, Lagos, Nigeria
}

${ }^{*}$ Corresponding author: Nwoko Valentine E, Formulation Pharmacist, Phamatex, Lagos, Nigeria, Tel: +2348026827847, E-mail: valentinenwoko@yahoo.com

Citation: Nwoko Valentine E (2014) Croscarmellose Sodium Efficiency in the Development of a Generic Capsule Formulation of Piroxicam, Comparable Dissolution Profile to the Innovator Product, Feldene. J Pharm Drug Devel 2(4): 401. doi: 10.15744/2348-9782.1.601

Received Date: July 07, 2014 Accepted Date: December 18, 2014 Published Date: December 22, 2014

\begin{abstract}
The objective of this study was to evaluate the encapsulation performance of Croscarmellose sodium, a superdisintegrant in a low-dose, poor-solubility drug formulation and the in-vitro dissolution performance of the Piroxicam capsules. Preparation, characterization and evaluation of the effects of the different concentrations of carmellose sodium and the amount of dried starch on in-vitro dissolution of Piroxicam capsules. Piroxicam was chosen for its very low solubility in biological fluids, which result in poor systemic bioavailability after oral administration. Piroxicam can be categorized as Class II drugs according to the Biopharmaceutics Classification System. This drug is poorly water soluble, but once dissolved, it is easily absorbed through the gastro-intestinal membrane. The innovator formula includes lactose as the main filler along with corn starch, sodium lauryl sulphate and magnesium stearate. A $3^{2}$ full factorial design was applied to investigate the combine effect of 2 formulation variable: Dried starch and Croscarmellose sodium. The systematic formulation approach helped in understanding the effect of formulation processing variables. Percent drug dissolved increased with increase in the level of superdisintegrant. These results show that Croscarmellose sodium can be successfully used to produce Piroxicam capsules $\mathrm{AB}$ bioequivalence rated to FELDENE, innovator products.
\end{abstract}

Keywords: Piroxicam; Capsules; Croscarmellose sodium; In vitro dissolution; Similarity factors

\section{Introduction}

Over the past decades, pharmaceuticals have made a major contribution in improving the health status of patients. At the same time, its expenditure has increased rapidly, with spending on medicines outpacing economic growth in many countries [1]. Since generic drug products are usually marketed at substantially lower prices than the original brand-name products and with the rising cost of healthcare; development of generics is an attractive option to healthcare providers and governments [2]. However since the regulatory expectations for approval of a generic drug product have become increasingly challenging and also to avoid setbacks at a later stages during the development, it is very important that sufficient efforts are made on generating the preformulation data at the initial stages during the development work for a generic formulation. A Generic drug product [3-5] is considered to be "essentially similar" or bioequivalent to an innovator (brand name) drug product. Bioequivalence implies that a generic drug product is essentially identical to the innovator drug (reference) drug product in term of active ingredient, strength, dosage form, route of administration, quality, safety, efficacy, performance characteristics and therapeutic effects. Generic drug product development may or may not use a different approach and strategy compared to that used to develop branded drug product containing a new chemical entity.

Piroxicam which is a member of the oxicam group of nonsteroidal anti-inflammatory drugs (NSAIDs). The chemical name for Piroxicam is 4-hydroxyl-2-methyl-N-2-pyridinyl-2H-1,2,-benzothiazine-3-carboxamide 1,1-dioxide. Piroxicam occurs as a white crystalline solid, sparingly soluble in water, dilute acid and most organic solvents. It is slightly soluble in alcohol and in aqueous solutions. It exhibits a weakly acidic 4-hydroxy proton (pKa 5.1) and weakly basic pyridyl nitrogen (pKa 1.8). The molecular weight of Piroxicam is 331.35. Its molecular formula is $\mathrm{C}_{15} \mathrm{H}_{13} \mathrm{~N}_{3} \mathrm{O}_{4} \mathrm{~S}$. Piroxicam is a potent anti-inflammatory drug. It is used in treatment of osteoarthritis, rheumatoid arthritis, ankylosing spondylitis and acute gout disease. It has prolonged half life of about 45 hrs. It is poorly water soluble drug and when administered orally it may cause bioavailability problems due to its poor solubility and dissolution rates in biological fluids. The marketed product of Piroxicam is available as imprinted hard shell capsules containing 20 mg of Piroxicam [6]. 
Among all the solid dosage forms, capsules are the second most popular dosage form to tablets on the market. However, capsules have frequently been considered as the first dosage form used in early clinical trials of a new drug for several reasons. Because of the pressure to expedite the formulation development and manufacture of clinical trial materials, capsules have been proven the best choice for powder filling and the most suitable dosage form for blinding purposes. Capsules can also be used to mask the taste and odour of the active drug contained within the capsule shells. Although a high compactibility characteristic is not a requirement for a capsule formulation to form a hard compact, the selection of excipients in the formula still remains critical to ensure good flow properties and lubrication of the blend on a tamp-filling machine [7]. If the formula is to be encapsulated on a dosator-type machine, then the blend should also have some binding properties to facilitate plug formation for the transfer to the capsule shells. A capsule formulation should have satisfactory powder fluidity, lubrication and compactibility for a successful manufacturing operation. The design of formulations also requires disintegration properties to promote deaggregation of the powder mass into primary drug particles and speed up the dissolution rate of the drug substance.

For capsules which need rapid disintegration, the inclusion of the right disintegrant is a prerequisite for optimal bioavailability. Superdisintegrant are used in cases where the cohesive powder released after dissolution of capsule shell fails to dissolve due to the lack of wetting or penetration of gastric fluid into it. Superdisintegrants are used to improve the efficacy of solid dosage forms. This is achieved by decreasing the disintegration time which in turn enhances drug dissolution rate. Superdisintegrants are widely used in capsule formulations. In order to closely match the functionality requirements, superdisintegrants which show outstanding disintegration characteristics for capsule formulations. Superdisintegrants are substances or mixture of substances added to tablet formulations to promote the break-up of the capsule "slugs" into smaller fragments in an aqueous environment thereby increasing the available surface area and promoting a more rapid release of the drug substance. Capsule disintegration has received considerable attention as an essential step in obtaining faster drug release. The emphasis on the availability of the drug highlights the importance of the relatively rapid disintegration of a tablet as a criterion for ensuring uninhibited drug dissolution behaviour. A number of factors affect the disintegration behaviour of capsules [8]. Recently, chemically modified disintegrants termed as superdisintegrants have been developed to improve the disintegration processes. Selection of appropriate formulation excipients and manufacturing technology can obtain the design feature of capsules. The disintegrants have the major function to oppose the efficiency of the capsules diluents. The proper choice of a disintegrant or a superdisintegrant and it's consist performance are of critical importance to the formulation development of such capsules. Drug release from a solid dosage form can be enhanced by addition of suitable disintegrants. An ideal disintegrant should have poor solubility, poor gel formation, good hydration capacity, good compressibility, flow properties and no tendency to form complexes with the drugs. Superdisintegrants: Sodium Starch Glycolate and Croscarmellose Sodium*, speed up drug dissolution by promoting liquid penetration (wicking) and promoting deaggregation. Efficiency often improves with increased tamping. Superdisintegrating agents are used in cases where the cohesive powder released after dissolution of capsule shell fails to dissolve due to the lack of wetting or penetration of gastric fluid into it. Effectively used at levels from 4-8\%. Crospovidone not as effective in capsules at equivalent concentrations equivalent concentrations. Superdisintegrants with a rapid and high degree of swelling play vital role in dissolution of poor water soluble drugs [9].

The objective of this study was to evaluate the encapsulation performance of Croscarmellose sodium, a superdisintegrant in a lowdose, poor-solubility drug formulation and the in-vitro dissolution performance of the resulting Piroxicam capsules. Preparation, characterization and evaluate the effects of the different concentrations of carmellose sodium and the amount of dried starch on: in-vitro disintegration and in-vitro dissolution, of Piroxicam capsules. Piroxicam was chosen for its very low solubility in biological fluids, which result in poor systemic bioavailability after oral administration. Piroxicam undergoes high first pass metabolism. Therefore its systemic bioavailability is low, which makes Piroxicam a suitable candidate for dispersible tablets. Piroxicam can be categorized as Class II drugs according to the Biopharmaceutics Classification System. This drug is poorly water soluble, but once dissolved, it is easily absorbed through the gastro-intestinal membrane. The innovator formula includes lactose as the main filler along with corn starch, sodium lauryl sulphate and magnesium stearate.

\section{Materials and Method}

\section{Materials}

Piroxicam (APEX, India), Lactose monohydrate (Danone GmbH, Germany), Croscarmellose sodium (Prachin, India), sodium lauryl sulphate (Vinamax, India) and magnesium stearate (Magnesia, Germany). All the other chemicals used were of analytical grade and obtained from commercial sources. Aluminium foils 180mm (INEOS) and PVC 184mm (Klockner Pentaplast).

\section{Instruments}

Auto Capsule filling machine (ACG AF 90T), UV-spectrophotometer (Shimadzu UV - 1800), Digital Balance (Adventure TM OHAUS), Dissolution apparatus (Electrolab Tablet Dissolution USP TESTER (TDL 082), Thickness (Electrolab Vernier calliper), Disintegration machine (Electrolab disintegration apparatus USP (Electrolab ED-2L). Humidity chamber for accelerated stability study (Memmert GmbH Germany). 
Softwares: Graphpad Instat 3.0, Design- Expert 9.0

\section{Characterization of Piroxicam Drug Substance}

A scanning electron microscope (SEM, model AMRAY 1830I) was used to examine the particle size and morphology at $20 \mathrm{kV}$ accelerating voltage. The samples were fixed by mutual conductive adhesive tape on aluminum stubs and covered with a $250 \mathrm{~A}^{\circ}$ film of gold-palladium using a sputter coater. Scanning Electron Micrographs (SEM) were also taken at 100x, 250x, 1000x and 2500x magnifications, with representative samples of Piroxicam drug substance (Figure 1).

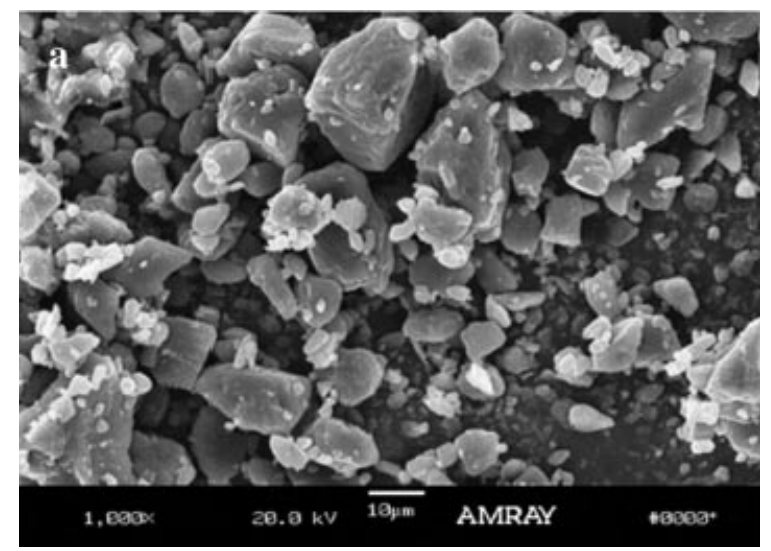

Figure 1: Scanning electron micrographs of Piroxicam

\section{Drug-excipient compatibility studies}

Compatibility Studies of PIROXICAM with various excipients: In early drug development phase, excipient compatibility studies are very important as it provides a rational basis for identification of low-risk excipients with physical and chemical compatibility to the drug substance. Drug excipient compatibility studies are critical for well-formulated final dosage forms where the drug reside in contact with one or more excipients during process scale-up from clinical trials through commercial to consumer. Performing these studies at the early development stage has the potential to both accelerate drug development and minimize the risk of drug product stability failure. The study designed as follows with different ratio for drug and excipients as per their functionality. The weighed amount of Piroxicam mixed well with a proposed proportion of individual excipients. Blend was filled and sealed in $5 \mathrm{ml}$ glass vials. Vials were subjected to $40{ }^{\circ} \mathrm{C} \pm 2{ }^{\circ} \mathrm{C} / 75 \% \pm 5 \% \mathrm{RH}$ for 4 weeks. The control samples were stored at $2-8{ }^{\circ} \mathrm{C}$. The samples were observed for physical changes like discoloration, liquefaction and analyzed (Table 1).

\begin{tabular}{|c|c|c|c|c|}
\hline $\mathrm{S} / \mathrm{N}$ & INGREDIENTS & RATIO TAKEN & OUANTITY TAKEN (g) & Condition \\
\hline 1 & PIROXICAM(API) & 1:0 & 1 & $40^{\circ} \pm 2^{\circ} \mathrm{C} / 75 \% \mathrm{RH} \pm 5 \%$ \\
\hline 2 & API + LACTOSE MONOHYDRATE & $1: 5$ & $0.5+0.25$ & $40^{\circ} \pm 2^{\circ} \mathrm{C} / 75 \% \mathrm{RH} \pm 5 \%$ \\
\hline 3 & API + MANNITOL & 1:5 & $0.5+0.25$ & $40^{\circ} \pm 2^{\circ} \mathrm{C} / 75 \% \mathrm{RH} \pm 5 \%$ \\
\hline 4 & $\begin{array}{c}\text { API + CROSS CARMELLOSE } \\
\text { SODIUM }\end{array}$ & $1: 5$ & $0.5+0.25$ & $40^{\circ} \pm 2^{\circ} \mathrm{C} / 75 \% \mathrm{RH} \pm 5 \%$ \\
\hline 5 & API + STARCH & $1: 5$ & $0.5+0.25$ & $40^{\circ} \pm 2^{\circ} \mathrm{C} / 75 \% \mathrm{RH} \pm 5 \%$ \\
\hline 6 & $\begin{array}{l}\text { API + SODIUM LAURYL SUL- } \\
\text { PHATE }\end{array}$ & $1: 5$ & $0.5+0.25$ & $40^{\circ} \pm 2^{\circ} \mathrm{C} / 75 \% \mathrm{RH} \pm 5 \%$ \\
\hline 7 & API + MAGNESIUM STEARATE & $1: 0.25$ & $1+0.25$ & $40^{\circ} \pm 2^{\circ} \mathrm{C} / 75 \% \mathrm{RH} \pm 5 \%$ \\
\hline
\end{tabular}

Table 1: Physical compatibility profile of Piroxicam

Evaluation of the reference product in USA: PPiroxicam (a non-steroidal anti-inflammatory agent) marketed in USA under the brand name Feldene ${ }^{\varpi}$ by Pfizer Laboratories Div Pfizer Inc (134489525). Feldene ${ }^{\varpi}$ (Piroxicam) capsules are available in 20mg strengths packs. The brief evaluation of Feldene ${ }^{\circledR}$ capsule $20 \mathrm{mg}$ (Reference Listed Product in USA) (Table 2) (Figure 2) (Table3). 


\begin{tabular}{|c|c|}
\hline Active ingredient & Piroxicam \\
\hline Dosage form & Capsule ( RED (Maroon)) \\
\hline Strength & FELDENE \\
\hline Brand name (innovator) & $315 \mathrm{mg}$ \\
\hline Average Filled weight & 2 \\
\hline Size & $18.1 \mathrm{~mm}$ \\
\hline Lock length (mm) & $\begin{array}{c}\text { Contents: } 1.15-1.5 \text { min / Capsule Shell: } 12-15 \\
\text { min }\end{array}$ \\
\hline Disintegration time & $\begin{array}{c}\text { Lactose monohydrate, corn starch, sodium lauryl } \\
\text { sulphate, magnesium stearate and edible inks and } \\
\text { gelatin. }\end{array}$ \\
\hline Excipients & \begin{tabular}{c} 
PVC/ALU Blisters of 10 capsules \\
\hline Packaging
\end{tabular} \\
\hline
\end{tabular}

Table 2: Evaluation of the reference product in USA

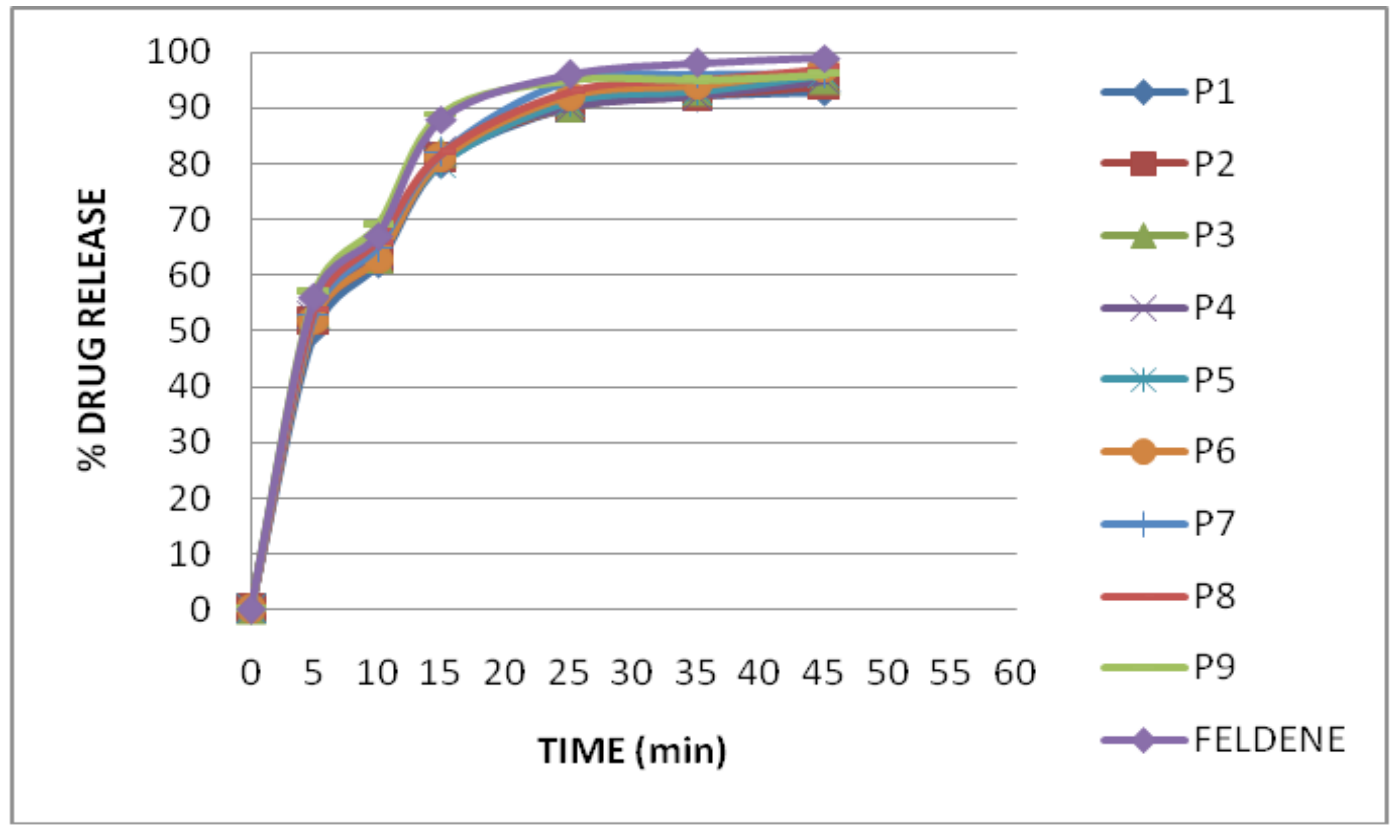

Figure 2: In vitro Drug Release Profile Of Batches And Feldene Product

\begin{tabular}{|c|c|}
\hline Ingredients & Function \\
\hline Piroxicam & API \\
\hline Lactose monohydrate & Diluents \\
\hline Dried Starch & Diluents/Disintegrant \\
\hline Croscarmellose sodium & Disintegrant \\
\hline Sodium Lauryl sulphate & Surfactant \\
\hline Magnesium stearate & Lubricants \\
\hline Capsule size & $\mathbf{2}$ \\
\hline Total weight $(\mathbf{m g})$ & $\mathbf{3 1 0 m g}$ \\
\hline
\end{tabular}

\section{Formulations}

Table 3: Formulation of Piroxicam Capsules 300mg

Sources and selection of excipients: These excipients have been chosen for the study based on the available information of reference product composition in package insert and the information available in patents. A simple formula was developed with the ingredients listed in the reference product. Each capsule contained $20 \mathrm{mg}$ of Piroxicam in a size 2 maroon red hard gelatin capsule shell. The blend was prepared by passing the lactose, cornstarch, sodium lauryl sulphate croscarmellose and Piroxicam through size \#30 mesh, then to a twin shell cage blender and mixed for 15 minutes at 10RPM. Prior to weighing, the magnesium stearate was passed through a 40 mesh screen then added to the blend and mixed for an additional 3 minutes (Table 5). 


\begin{tabular}{|c|c|c|c|c|c|c|c|c|}
\hline \multirow{2}{*}{$\begin{array}{c}\text { Batch } \\
\text { code }\end{array}$} & \multicolumn{2}{|c|}{ Variables } & \multicolumn{6}{|c|}{ INGREDIENTS } \\
\cline { 2 - 8 } & $\mathbf{X}_{1}$ & $\mathbf{X}_{2}$ & Piroxicam & Lactose & Dried starch & $\begin{array}{c}\text { Croscarmellose } \\
\text { sodium }\end{array}$ & $\begin{array}{c}\text { Sodium lauryl } \\
\text { sulphate }\end{array}$ & $\begin{array}{c}\text { Magnesium } \\
\text { stearate }\end{array}$ \\
\hline P1 & -1 & -1 & 20 & 233 & 27.93 & 18.6 & 1.5 & 2.75 \\
\hline P2 & -1 & 0 & 20 & 233 & 31.0 & 18.6 & 1.5 & 2.75 \\
\hline P3 & -1 & 1 & 20 & 233 & 34.16 & 18.6 & 1.5 & 2.75 \\
\hline P4 & 0 & -1 & 20 & 233 & 27.93 & 21.7 & 1.5 & 2.75 \\
\hline P5 & 0 & 0 & 20 & 233 & 31.0 & 21.7 & 1.5 & 2.75 \\
\hline P6 & 0 & 1 & 20 & 233 & 34.16 & 21.7 & 1.5 & 2.75 \\
\hline P7 & 1 & -1 & 20 & 233 & 27.93 & 24.8 & 1.5 & 2.75 \\
\hline P8 & 1 & 0 & 20 & 233 & 31.0 & 24.8 & 1.5 & 2.75 \\
\hline P9 & 1 & 1 & 20 & 233 & 34.16 & 24.8 & 1.5 & 2.75 \\
\hline
\end{tabular}

Table 5: Composition of Piroxicam Capsules

The moisture content of the final blend was measured using a Instrument IR-20 moisture balance at a temperature of $105^{\circ} \mathrm{C}$. The particle size distribution of the blend was performed with a sample of $10 \pm 0.1$ grams on an ATM Sonic Sifter set up at 5 minutes of testing time, amplitude 4 and sift-pulse mode. The bulk and tapped density were performed in accordance with USP Method 1. The geometric mean diameter of granules and standard deviation were calculated based on a weight cumulative frequency-particle size distribution plotted on a log-probability scale (Table 6).

\begin{tabular}{|c|c|c|c|c|c|}
\hline Material & Initial observation & $\begin{array}{c}\text { Drug } \\
\text { Excipients } \\
\text { ratio }\end{array}$ & $\begin{array}{c}\text { Observation } \\
\text { at the end of } \\
\mathbf{1}^{\text {st }} \text { month }\end{array}$ & $\begin{array}{c}\text { Observation } \\
\text { at the end of } \\
\mathbf{2}^{\text {nd }} \text { month }\end{array}$ \\
\hline Piroxicam (as control) & A white powder & I & No colour change & No colour change & No colour change \\
\hline API + lactose monohydrate & A white powder & $1: 11$ & No colour change & No colour change & No colour change \\
\hline API + croscarmellose sodium & A white powder & $1: 0.5$ & No colour change & No colour change & No colour change \\
\hline API + sodium lauryl sulphate & A white powder & $1: 0.5$ & No colour change & No colour change & No colour change \\
\hline API + dried lactose & A white powder & $1: 0.25$ & No colour change & No colour change & No colour change \\
\hline API + magnesium stearate & A white powder & $1: 0.25$ & No colour change & No colour change & No colour change \\
\hline
\end{tabular}

Table 6: Physical compatibility profile of Piroxicam

Encapsulation and Physical Testing of Filled Capsules: Encapsulation was conducted on a AF90T machine (ACG Pam), set up for hard gelatin shells size \#2, with a dosing disc of $19.5 \mathrm{~mm}$ thickness, and encapsulation speed of $500 \mathrm{capsules} / \mathrm{hr}$. The pin settings were set in ascending order of $3.5 \mathrm{~mm}, 6.0 \mathrm{~mm}, 6.0 \mathrm{~mm}$, and $7.0 \mathrm{~mm}$. A composite sample of capsules collected from the bulk was tested for weight variation on an Erweka Multicheck.

\section{Evaluation of Piroxicam $(20 \mathrm{mg})$ filled capsules}

Weight uniformity of filled capsules: Randomly selected twenty capsules were weighed individually and together. Average weight was calculated. Each individual capsules weight was compared against the calculated average. The USP method was used for this experiment.

Lock length: The lock length of the filled capsules was tested using a digital Electrolab Vernier calliper tester. This test was conducted according to the USP specification. 20 randomly selected capsules from each of three study batches were tested at the different time intervals of the study.

Disintegration test of filled capsules: The disintegration time of Piroxicam $20 \mathrm{mg}$ capsules was determined according to the procedure reported in USP (USP 2007). Six capsules of Piroxicam $20 \mathrm{mg}$ capsules were weighed individually and placed were in $600 \mathrm{ml} 0.1 \mathrm{~N} \mathrm{HCL}$ according to the USP method, with disc at $37^{\circ} \mathrm{C} \pm 2{ }^{\circ} \mathrm{C}$. The disintegration times of 6 individual tablets were recorded and the average disintegration time was noted.

Assay for filled Capsules: The amount of Piroxicam in each capsule was determined according to the USP assay method (USP 2007).

\section{Dissolution Test Method}

The dissolution method for Piroxicam capsules is not currently posted in the USP 29 Monographs. The dissolution test was performed following the recommendations from the FDA. 


\begin{tabular}{|c|c|c|c|c|}
\hline Drug name & Dosage form & USP Apparatus & Speed (rpm) & Medium \\
\hline Piroxicam & Capsule & II paddle & 50 & $\begin{array}{c}\text { simulated gastric fluid TS, prepared } \\
\text { without pepsin }\end{array}$ \\
\hline
\end{tabular}

\begin{tabular}{|c|c|c|c|}
\hline Temperature & Volume & Sampling Time (minutes) & Date updated \\
\hline $37 \pm 0.5^{\circ} \mathrm{C}$ & $900 \mathrm{mls}$ & $5,10,15,25,35$ and 45 & $01 / 06 / 2014$ \\
\hline
\end{tabular}

\section{Analysis of In Vitro Drug Release Data}

$\mathrm{D}_{5 \min }, \mathrm{D}_{10 \min }, \mathrm{DE}_{30 \min }, \mathrm{T}_{25 \%}, \mathrm{~T}_{50 \%}, \mathrm{~T}_{90 \%}$. $\mathrm{D} 5$ is percent drug released in $5 \mathrm{~min} . \mathrm{D}_{10}$ is percent drug release in $10 \mathrm{~min}$. $\mathrm{T}_{25 \%}$ is time for $25 \%$ drug dissolution $\mathrm{T}_{50 \%}$ is time for $50 \%$ drug dissolution. $\mathrm{T}_{90 \%}$ is time for $90 \%$ drug dissolution (Figure 3 ).

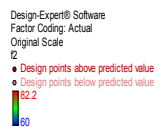

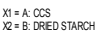
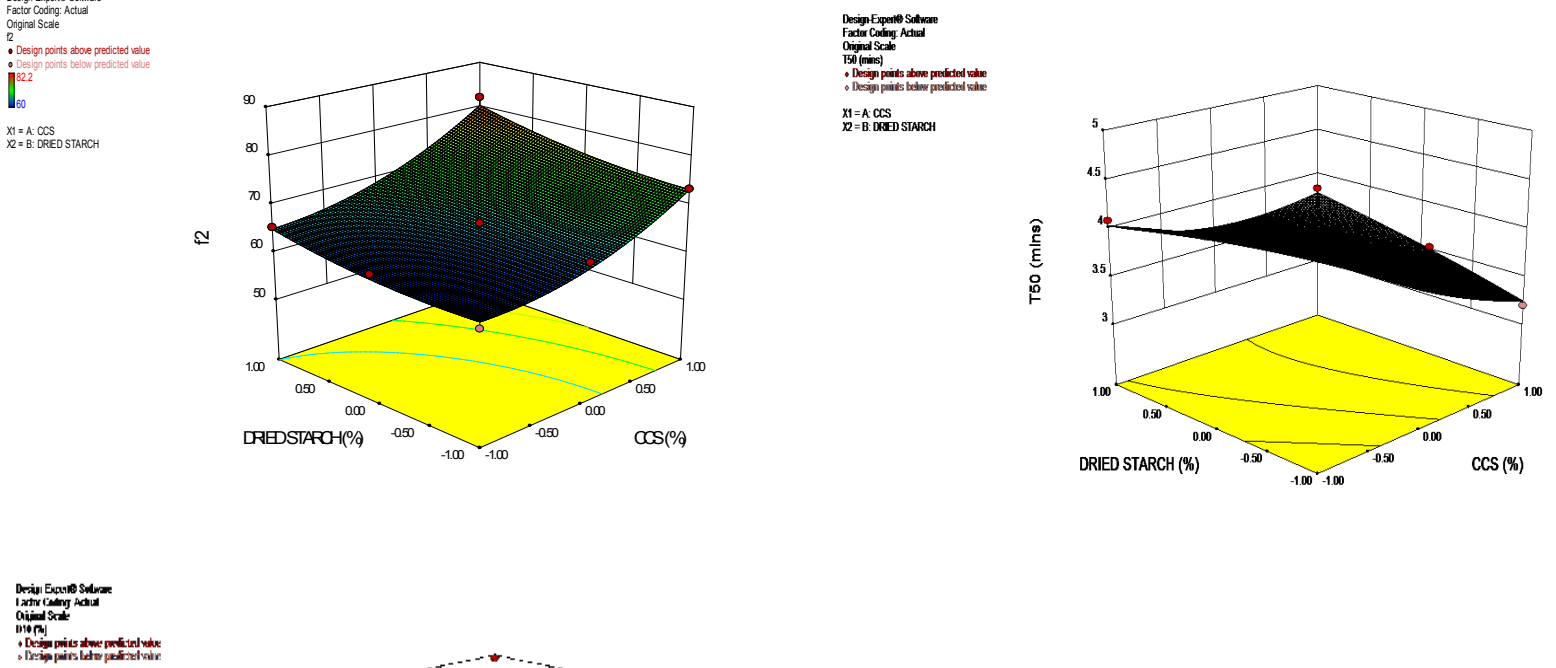

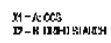

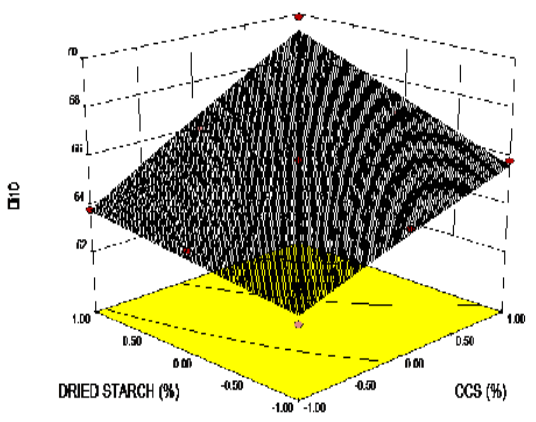

Figure 3: Response surface plot for $\mathrm{f}_{2}, \mathrm{~T}_{50 \%}, \mathrm{D}_{10 \mathrm{mins}}$

$\mathrm{DE}$ is defined as the area under the dissolution curve up to time $t$ expressed as a percentage of the rectangle described by $100 \%$ dissolution in the same time where $y t$ is the percentage of drug dissolved at any time $t, y 100$ denotes $100 \%$ dissolution, and the integral represents the area under dissolution curve between time zero and $t$. Time $t$ in this study was 30 minutes [10].

$\mathrm{DE} \Rightarrow$ dissolution efficiency $=\frac{\int_{0}^{t} y x d t}{y_{100} x t} \quad x \quad 100, \mathrm{Y}=$ percentage of drug dissolved at time $(\mathrm{t})$ OR DE $(\%)=$ Shaded Area

$\overline{\text { Rectangle area }(y 100 x t)}$

$\Rightarrow \frac{\int_{0}^{t} y x d t}{y_{100 x t}} \times 100$

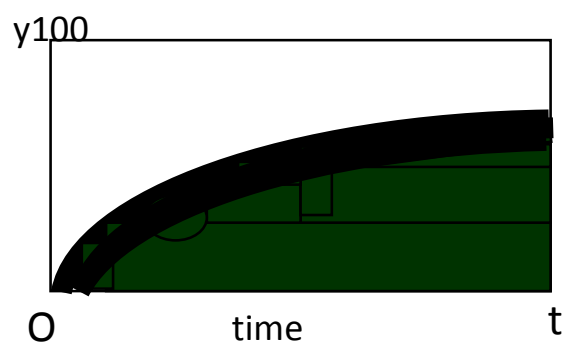




\section{Similarity and Dissimilarity Factors}

A model independent approach was used to estimate dissimilarity factor $\left(f_{1}\right)$ and similarity factor $\left(f_{2}\right)$ to compare dissolution profiles. The following equations were used for calculating $f_{1}$ and $f_{2}$.

$f_{1}=\left[\frac{\left[\sum_{t=1}^{n}\left(R_{t}-T_{t}\right)\right]}{\left[\sum_{t=1}^{n} R_{t}\right]}\right] \times 100$ Equation 1.0

The similarity factor $\left(f_{2}\right)$ is given by following equation:

$f_{2}=50 \times \log \left[\left(1+\frac{1}{n} \sum_{t=1}^{n}\left(R_{t}-T_{t}\right)^{-0.5}\right) X 100\right] \ldots \ldots \ldots \ldots \ldots \ldots . . .$. Equation 1.1

Where, $\mathrm{n}$ is number of pull points, $\mathrm{R}_{\mathrm{t}}$ is the reference batch profile at time $\mathrm{t}$ and $\mathrm{T}_{\mathrm{t}}$ is the test batch profile at the same time point. For in vitro dissolution curves to be considered similar, the value of $f_{1}$ should be in the range of 0 - 15 while the value of $f_{2}$ should lie within 50-100 [11].

The similarity factor $\left(f_{2}\right)$ is a logarithmic transformation of the sum-squared error of differences between the test $\mathrm{T}_{\mathrm{t}}$ and reference $\mathrm{R}_{\mathrm{t}}$ products over all time points. The similarity factor fits result between 0 and 100. It is 100 when the test and reference profiles are identical and tends to 0 as the dissimilarity increases. This method is more adequate to dissolution profile comparisons when more than three or four dissolution time points are available. In order to consider similar dissolution profiles, the $f_{1}$ values should be close to 0 and $f_{2}$ values should be close to 100 . In general, $f_{1}$ values lower than $15(0-15)$ and $f_{2}$ values higher than 50 (50-100) show the similarity of the dissolution profiles.

\section{Statistical Analysis}

Each tablet formulation was reared in duplicate and each analysis was duplicated. Each formulation variables on disintegration time and release parameters was tested for significance by using analysis of variance (ANOVA). Difference was considered significant when $\mathrm{P}<0.05$ (Table 15).

\begin{tabular}{|c|c|c|c|c|c|c|c|c|c|c|}
\hline Source & $\begin{array}{l}\text { Sum of } \\
\text { squares }\end{array}$ & $\begin{array}{l}\text { Degrees } \\
\text { of Freedom }\end{array}$ & $\begin{array}{l}\text { Mean } \\
\text { Square }\end{array}$ & VIF & F Value & P Value & R-Square & $\begin{array}{l}\text { Adj R } \\
\text { Square }\end{array}$ & $\begin{array}{l}\text { Pred } \\
\text { Square }\end{array}$ & $\begin{array}{c}\text { Adeq } \\
\text { Precision }\end{array}$ \\
\hline \multicolumn{11}{|l|}{$\left(f_{2}\right)$} \\
\hline $\mathrm{X}_{1}$ & 278.80 & 1 & 278.8 & 1 & 48.42 & 0.0061 & 0.9531 & 0.8750 & 0.4562 & 9.714 \\
\hline $\mathrm{X}_{2}$ & 43.74 & 1 & 43.74 & 1 & 7.66 & 0.0704 & & & & \\
\hline $\mathrm{X}_{1} \mathrm{X}_{2}$ & 2.89 & 1 & 2.89 & 1 & 0.50 & 0.5298 & & & & \\
\hline $\mathrm{X}_{1}^{2}$ & 22.0 & 1 & 22.0 & 1 & 3.82 & 0.1456 & & & & \\
\hline $\mathrm{X}_{2}^{2}$ & 3.74 & 1 & 3.74 & 1 & 0.65 & 0.4795 & & & & \\
\hline \multicolumn{11}{|c|}{$\left(\mathrm{D}_{5 \min }(\%)\right)$} \\
\hline $\mathrm{X}_{1}$ & 26.8 & 1 & 26.8 & 1 & 43.48 & 0.0071 & 0.9520 & 0.8719 & 0.4657 & 10.249 \\
\hline $\mathrm{X}_{2}$ & 8.28 & 1 & 8.28 & 1 & 13.41 & 0.0352 & & & & \\
\hline $\mathrm{X}_{1} \mathrm{X}_{2}$ & 1.63 & 1 & 1.63 & 1 & 2.63 & 0.2032 & & & & \\
\hline $\mathrm{X}_{1}^{2}$ & 0.02 & 1 & 0.02 & 1 & 0.037 & 0.8687 & & & & \\
\hline $\mathrm{X}_{2}^{2}$ & $5.0 \mathrm{E}-005$ & 1 & 5.0E-005 & 1 & 5.0E-005 & 0.9934 & & & & \\
\hline \multicolumn{11}{|c|}{ ( $\mathrm{T}_{50 \%}$ mins) } \\
\hline $\mathrm{X}_{1}$ & 2.59 & 1 & 2.59 & 1 & 375.22 & 0.0003 & 0.9936 & 0.9830 & 0.9221 & 28.73 \\
\hline $\mathrm{X}_{2}$ & 0.41 & 1 & 0.41 & 1 & 58.82 & 0.0046 & & & & \\
\hline $\mathrm{X}_{1} \mathrm{X}_{2}$ & 0.16 & 1 & 0.16 & 1 & 23.79 & 0.0165 & & & & \\
\hline $\mathrm{X}_{1}^{2}$ & $1.422 \mathrm{E}-003$ & 1 & $1.422 \mathrm{E}-003$ & 1 & 0.21 & 0.6806 & & & & \\
\hline $\mathrm{X}_{2}^{2}$ & 0.06 & 1 & 0.06 & 1 & 0.71 & 0.0599 & & & & \\
\hline
\end{tabular}

Table 15: Summary of ANOVA table for dependent variables from a full factorial design of Piroxicam capsules 


\section{Results and Discussion}

\section{Particle size distribution}

Particle size distribution was calculated using the polydisperse model and the following refractive indices and results were obtained:

Particle RI: 1.53

\begin{tabular}{llll}
\multicolumn{3}{c}{ Imaginary RI:1.0 } & Dispersant RI : 1.38 \\
$\mathbf{D}(\mathbf{v}, \mathbf{0 . 1})$ & $\mathrm{D}(\mathbf{v}, \mathbf{0 . 5})$ & $\mathrm{D}(\mathbf{v}, \mathbf{0 . 9})$ & $\mathrm{D}[\mathbf{4}, \mathbf{3}]$ \\
68.709 & 152.236 & 355.493 & 187.245
\end{tabular}

All sizes are reported in microns, and are expressed as volume \% undersize. The value of D [4,3] is the mean particle diameter.

\section{Micromeritics of Final Blend}

The blend properties of the Piroxicam formula are summarized below. The compressibility index or Carr's index is commonly used to predict the flowability of powder. The Carr's compressibility index of 12-15\% indicated satisfactory flow properties of the final blend that was then verified with a low weight variation of capsule fill weight as below (Table 7).

\begin{tabular}{|c|c|c|c|c|c|c|c|c|c|c|}
\hline \multirow{2}{*}{$\begin{array}{l}\text { Batch } \\
\text { code }\end{array}$} & \multicolumn{2}{|c|}{ Variables } & \multicolumn{8}{|c|}{ MICROMERITICS } \\
\hline & $\mathrm{X}_{1}$ & $\mathbf{X}_{2}$ & $\begin{array}{l}\text { Loss on } \\
\text { Drying }\end{array}$ & $\begin{array}{l}\text { Bulk } \\
\text { density } \\
\mathrm{g} / \mathrm{cm}^{3}\end{array}$ & $\begin{array}{l}\text { Tapped } \\
\text { density } \\
\mathrm{g} / \mathrm{cm}^{3}\end{array}$ & $\begin{array}{l}\text { Angle } \\
\text { of repose }\end{array}$ & $\begin{array}{l}\text { Hausner } \\
\text { Quotient }\end{array}$ & $\begin{array}{l}\text { Geometric } \\
\text { mean } \\
\text { diameter }\end{array}$ & $\begin{array}{l}\text { Geometric } \\
\text { Standard } \\
\text { deviation }\end{array}$ & $\begin{array}{l}\text { Carr's } \\
\text { index }\end{array}$ \\
\hline $\mathrm{P} 1$ & -1 & -1 & $2.42 \%$ & 0.257 & 0.344 & 32.43 & 1.13 & 146 micron & 1.75 & 13.34 \\
\hline P2 & -1 & 0 & $2.42 \%$ & 0.248 & 0.248 & 30.09 & 1.15 & 146 micron & 1.75 & 14.46 \\
\hline P3 & -1 & 1 & $2.42 \%$ & 0.254 & 0.254 & 33.76 & 1.12 & 146 micron & 1.75 & 13.29 \\
\hline $\mathrm{P} 4$ & 0 & -1 & $2.42 \%$ & 0.256 & 0.256 & 31.89 & 1.13 & 146 micron & 1.75 & 12.98 \\
\hline P5 & 0 & 0 & $2.42 \%$ & 0.251 & 0.251 & 33.56 & 1.12 & 146 micron & 1.75 & 14.67 \\
\hline P6 & 0 & 1 & $2.42 \%$ & 0.260 & 0.260 & 33.08 & 1.14 & 146 micron & 1.75 & 14.59 \\
\hline P7 & 1 & -1 & $2.42 \%$ & 0.254 & 0.254 & 32.65 & 1.12 & 146 micron & 1.75 & 15.09 \\
\hline P8 & 1 & 0 & $2.42 \%$ & 0.259 & 0.259 & 32.09 & 1.14 & 146 micron & 1.75 & 15.34 \\
\hline P9 & 1 & 1 & $2.42 \%$ & 0.263 & 0.263 & 33.82 & 1.13 & 146 micron & 1.75 & 13.62 \\
\hline
\end{tabular}

Table 7: Micromeritic of Piroxicam Blend

\section{Formula}

Properties of Capsules: A composite sample of empty hard gelatin capsule shells and filled capsules were tested for weight variation with the results presented in Table7,8,9. The values for the empty shells and filled capsules were used to calculate the variation statistics of the capsule fill weight (Table 8). The capsule fill weight of individual filled capsule was calculated by subtracting the average weight of empty shells from the actual weight of filled capsules (Table 9).

\begin{tabular}{|c|c|c|c|c|c|c|c|c|}
\hline Statistics & $\begin{array}{c}\text { No of } \\
\text { units tested }\end{array}$ & $\begin{array}{c}\text { Average } \\
\text { weight }\end{array}$ & $\begin{array}{c}\text { Standard } \\
\text { deviation } \mathbf{( m g )}\end{array}$ & RSD\% & $\begin{array}{c}\text { Min } \\
\text { weight } \\
\text { (mg) }\end{array}$ & $\begin{array}{c}\text { Max } \\
\text { weight } \\
\text { (mg) }\end{array}$ & $\begin{array}{c}\text { Spread } \\
\text { (\% of } \\
\text { mean) }\end{array}$ & $\begin{array}{c}\text { Target } \\
\text { capsule fill } \\
\text { weight(mg) }\end{array}$ \\
\hline Empty shells & 50 & 60 & 1.85 & 1.05 & 59.75 & 62.45 & \pm 2.56 & 60 \\
\hline
\end{tabular}

Table 8: Properties of Empty Capsules

A low RSD\% value for the capsule fill weight indicates excellent flow properties of the blend. Furthermore, a low spread of less than $5 \%$ of the mean provides strong evidence of the uniformity of capsule fill weight throughout the run. According to USP 30 , the requirements for weight variation of capsules are met if each of the individual weights is within the limits of $90 \%$ and $110 \%$ of the average weight. The actual average weight of the run was $368 \mathrm{mg}$ (Table 10).

The calculated percent values of $95.7 \%$ and $104.2 \%$ of the average capsule fill weight are well within the USP specification limits. The content uniformity of Piroxicam capsules was tested with 10 capsules sampled from the bulk. The assay result of individual capsules lies within the USP acceptance criteria range of $85.0 \%$ to $115.0 \%$ of the label claim, and the RSD is less than or equal to 6.0\% (Table 11). 


\begin{tabular}{|c|c|c|c|c|c|c|c|c|c|c|}
\hline \multirow{2}{*}{$\begin{array}{l}\text { Batch } \\
\text { code }\end{array}$} & \multicolumn{2}{|c|}{ Variables } & \multicolumn{8}{|c|}{ CAPSULES FILL WEIGHT } \\
\hline & $\mathrm{X}_{1}$ & $X_{2}$ & $\begin{array}{l}\text { No of units } \\
\text { tested }\end{array}$ & $\begin{array}{l}\text { Average } \\
\text { weight }\end{array}$ & $\begin{array}{c}\text { Standard } \\
\text { deviation }(\mathbf{m g})\end{array}$ & RSD\% & $\begin{array}{l}\text { Min weight } \\
\text { (mg) }\end{array}$ & $\begin{array}{l}\text { Max weight } \\
\text { (mg) }\end{array}$ & $\begin{array}{l}\text { Spread (\% } \\
\text { of mean) }\end{array}$ & $\begin{array}{l}\text { Target capsule } \\
\text { fill weight }(\mathrm{mg})\end{array}$ \\
\hline P1 & -1 & -1 & 70 & 310.45 & 5.65 & 2.01 & 302.45 & 319.45 & $\pm 3.32 \%$ & 310 \\
\hline $\mathrm{P} 2$ & -1 & 0 & 70 & 313.11 & 5.46 & 2.32 & 305.21 & 319.39 & $\pm 3.27 \%$ & 310 \\
\hline P3 & -1 & 1 & 70 & 310.45 & 5.42 & 2.11 & 304.67 & 322.33 & $\pm 3.05 \%$ & 310 \\
\hline $\mathrm{P} 4$ & 0 & -1 & 70 & 310.45 & 5.27 & 2.24 & 300.45 & 309.49 & $\pm 2.9 \%$ & 310 \\
\hline P5 & 0 & 0 & 70 & 310.45 & 5.34 & 2.25 & 305.45 & 321.45 & $\pm 3.34 \%$ & 310 \\
\hline P6 & 0 & 1 & 70 & 310.45 & 5.24 & 2.16 & 304.11 & 317.45 & $\pm 3.11 \%$ & 310 \\
\hline P7 & 1 & -1 & 70 & 310.45 & 5.09 & 2.13 & 300.35 & 311.24 & $\pm 3.09 \%$ & 310 \\
\hline P8 & 1 & 0 & 70 & 313.34 & 5.23 & 2.23 & 302.45 & 319.45 & $\pm 3.7 \%$ & 310 \\
\hline P9 & 1 & 1 & 70 & 314.37 & 5.65 & 2.44 & 307.45 & 324.45 & $\pm 3.3 \%$ & 310 \\
\hline Anova & & & $\mathrm{P}>0.05 \mathrm{NS}$ & $\mathrm{P}>0.05 \mathrm{NS}$ & $\mathrm{P}>0.05 \mathrm{NS}$ & $\mathrm{P}>0.05 \mathrm{NS}$ & $\mathrm{P}>0.05 \mathrm{NS}$ & $\mathrm{P}>0.05 \mathrm{NS}$ & $\mathrm{P}>0.05 \mathrm{NS}$ & $\mathrm{P}>0.05 \mathrm{NS}$ \\
\hline
\end{tabular}

NS $\rightarrow$ not significant, NQS $\rightarrow$ not quite significant, $S \rightarrow$ significant, VS $\rightarrow$ very significant, ES $\rightarrow$ extremely significant.

Table 9: Properties of Filled Capsules Content

\begin{tabular}{|c|c|c|c|c|c|c|c|c|c|c|}
\hline \multirow{2}{*}{$\begin{array}{l}\text { Batch } \\
\text { code }\end{array}$} & \multicolumn{2}{|c|}{ Variables } & \multicolumn{8}{|c|}{ FILLED CAPSULES } \\
\hline & $\mathbf{X}_{1}$ & $\mathrm{X}_{2}$ & $\begin{array}{l}\text { No of units } \\
\text { tested }\end{array}$ & $\begin{array}{c}\text { Average } \\
\text { weight }\end{array}$ & $\begin{array}{c}\text { Standard } \\
\text { deviation }(\mathbf{m g})\end{array}$ & RSD\% & $\begin{array}{c}\text { Min weight } \\
(\mathrm{mg})\end{array}$ & $\begin{array}{l}\text { Max weight } \\
(\mathrm{mg})\end{array}$ & $\begin{array}{c}\text { Spread (\% } \\
\text { of mean) }\end{array}$ & $\begin{array}{l}\text { Target capsule } \\
\text { fill weight(mg) }\end{array}$ \\
\hline $\mathrm{P} 1$ & -1 & -1 & 70 & 377.34 & 5.65 & 2.36 & 358.32 & 386.56 & $\pm 4.32 \%$ & 370 \\
\hline $\mathrm{P} 2$ & -1 & 0 & 70 & 376.09 & 5.46 & 2.31 & 360.97 & 386.85 & $\pm 4.37 \%$ & 370 \\
\hline P3 & -1 & 1 & 70 & 374.77 & 5.42 & 2.39 & 357.23 & 387.37 & $\pm 4.29 \%$ & 370 \\
\hline $\mathrm{P} 4$ & 0 & -1 & 70 & 379.08 & 5.27 & 2.34 & 355.67 & 386.34 & $\pm 4.38 \%$ & 370 \\
\hline P5 & 0 & 0 & 70 & 373.65 & 5.34 & 2.36 & 356.33 & 388.68 & $\pm 4.39 \%$ & 370 \\
\hline P6 & 0 & 1 & 70 & 375.08 & 5.24 & 2.37 & 356.33 & 386.08 & $\pm 4.41 \%$ & 370 \\
\hline P7 & 1 & -1 & 70 & 378.87 & 5.09 & 2.39 & 357.65 & 387.61 & $\pm 4.29 \%$ & 370 \\
\hline P8 & 1 & 0 & 70 & 376.89 & 5.23 & 2.40 & 356.89 & 388.78 & $\pm 4.30 \%$ & 370 \\
\hline P9 & 1 & 1 & 70 & 373.44 & 5.65 & 2.41 & 355.67 & 388.90 & $\pm 4.34 \%$ & 370 \\
\hline Anova & & & $\mathrm{P}>0.05 \mathrm{NS}$ & $\mathrm{P}>0.05 \mathrm{NS}$ & $\mathrm{P}>0.05 \mathrm{NS}$ & $\mathrm{P}>0.05 \mathrm{NS}$ & $\mathrm{P}>0.05 \mathrm{NS}$ & $\mathrm{P}>0.05 \mathrm{NS}$ & $\mathrm{P}>0.05 \mathrm{NS}$ & $\mathrm{P}>0.05 \mathrm{NS}$ \\
\hline
\end{tabular}

NS $\rightarrow$ not significant, NQS $\rightarrow$ not quite significant, $S \rightarrow$ significant, $V S \rightarrow$ very significant, ES $\rightarrow$ extremely significant.

Table 10: Properties of Filled Capsules

\begin{tabular}{|c|c|c|c|c|c|c|c|c|c|c|}
\hline \multirow{2}{*}{$\begin{array}{l}\text { Batch } \\
\text { code }\end{array}$} & \multicolumn{2}{|c|}{ Variables } & \multicolumn{8}{|c|}{ FILLED CAPSULES } \\
\hline & $\mathbf{X}_{1}$ & $X_{2}$ & $\begin{array}{l}\text { No of units } \\
\text { tested }\end{array}$ & $\begin{array}{l}\text { DT } \\
(\operatorname{mins})\end{array}$ & $\begin{array}{l}\text { Standard } \\
\text { deviation (mins) }\end{array}$ & RSD\% & $\begin{array}{l}\text { No of units } \\
\text { tested }\end{array}$ & $\begin{array}{l}\text { Lock length } \\
(\mathrm{mm})\end{array}$ & $\begin{array}{l}\text { Average } \\
\text { Content } \\
\text { Uniformity } \\
(\%)\end{array}$ & $\begin{array}{l}\text { Target capsule } \\
\text { fill weight }(\mathbf{m g})\end{array}$ \\
\hline $\mathrm{P} 1$ & -1 & -1 & 12 & 3.20 & 0.55 & 1.99 & 12 & 17.43 & 101.3 & 310 \\
\hline $\mathrm{P} 2$ & -1 & 0 & 12 & 3.10 & 0.73 & 1.89 & 12 & 17.12 & 101.3 & 310 \\
\hline P3 & -1 & 1 & 12 & 2.59 & 0.67 & 1.76 & 12 & 17.39 & 101.3 & 310 \\
\hline $\mathrm{P} 4$ & 0 & -1 & 12 & 2.57 & 0.70 & 1.94 & 12 & 17.07 & 101.3 & 310 \\
\hline P5 & 0 & 0 & 12 & 2.59 & 0.89 & 1.63 & 12 & 17.32 & 101.3 & 310 \\
\hline P6 & 0 & 1 & 12 & 2.54 & 0.75 & 2.00 & 12 & 17.38 & 101.3 & 310 \\
\hline P7 & 1 & -1 & 12 & 2.49 & 0.89 & 2.08 & 12 & 17.23 & 101.3 & 310 \\
\hline P8 & 1 & 0 & 12 & 2.29 & 0.54 & 2.21 & 12 & 17.35 & 101.3 & 310 \\
\hline P9 & 1 & 1 & 12 & 2.10 & 0.61 & 2.16 & 12 & 17.45 & 101.3 & 310 \\
\hline Anova & & & $\mathrm{P}>0.05 \mathrm{NS}$ & $\mathrm{P}<0.05$ VS & $\mathrm{P}>0.05 \mathrm{NQS}$ & $\mathrm{P}>0.05 \mathrm{NS}$ & $\mathrm{P}>0.05 \mathrm{NS}$ & $\mathrm{P}>0.05 \mathrm{NS}$ & $\mathrm{P}>0.05 \mathrm{NS}$ & \\
\hline
\end{tabular}

$\mathrm{NS} \rightarrow$ not significant, NQS $\rightarrow$ not quite significant, $\mathrm{S} \rightarrow$ significant, VS $\rightarrow$ very significant, ES $\rightarrow$ extremely significant.

Table 11: Properties of Filled Capsules 
Dissolution of Capsules: Dissolution profiles of batches, P1-P9 were generated to compare with the innovator capsules. A slightly faster release was observed at the 5-minute test point in the profile. Piroxicam capsules are considered to be rapidly dissolving products with more than $85 \%$ of the drug released in 15 minutes or less. The in-vitro performance of the formulated Piroxicam capsules is similar to innovator based on the $f_{2}$ values greater than 50 . The order of enhancement of the dissolution rate by increasing the concentration of croscarmellose sodium was found to be $6 \%>7 \%>8 \%$.

Analysis of In vitro Dissolution Data: From this data, it is evident that, increasing the concentration of croscarmelose sodium in the formulation brought about improved dissolution parameters.

\section{Factorial Design}

A two -factor three-level full factorial design was employed to study of combination of croscarmellose sodium and dried starch on the dependent variables like disintegration time and percent drug dissolved using the Design Expert Software (Version 9.0). The responses given by the software are expressed in terms of the quadratic polynomial equations which are given below. The polynomial equations can also be used to draw conclusions considering the magnitude of co-efficient and the mathematical sign it carries; i.e. positive or negative.

$$
\mathrm{Y}=\mathrm{b}_{0}+\mathrm{b}_{1} \mathrm{X}_{1}-\mathrm{b}_{2} \mathrm{X}_{2}+\mathrm{b}_{12} \mathrm{X}_{1} \mathrm{X}_{2}-\mathrm{b}_{1} \mathrm{X}_{1}^{2}+\mathrm{b}_{2} \mathrm{X}_{2}^{2}
$$

Equation 2.0

Where $\mathrm{Y}$ is the dependent variable: $\mathrm{b}_{0}$ is the arithmetic mean response of the nine runs and $\mathrm{b}_{1}$ is the estimated coefficient for the factors $\mathrm{X}_{1}$. The main effects represent the average results of changing one factor from its low to high values. The interaction term $\left(\mathrm{X}_{1} \mathrm{X}_{2}\right)$ shows how the response values changes when two factors are simultaneously changed. Equation 2.0 can be used to draw conclusion after considering the magnitude of coefficients and the mathematical sign that the coefficients carries. A high positive or negative value in the equation represent that by making a minor change in the setting of that factor one may obtain a significant change in the dependent variable. The data shown in Table 3 and 11 reveals that independent variables $\left(\mathrm{X}_{1}\right.$ and $\left.\mathrm{X}_{2}\right)$ exhibit a great influence on response (Table 4). The model relating the selected responses to the transformed factors are shown in Table 12. It can be concluded that a good fit was found for all responses. The $\mathrm{f}_{2}, \mathrm{D}_{10 \min }$ and $\mathrm{T}_{50 \%}$ for the nine batches (P1-P9) showed a wide variation (i.e., 60-82.2, 62.32-69.86\% and 5.0-3.0 mins, respectively). The responses of the formulations prepared by $3^{2}$ factorial design batches are shown in (Table 12). The data clearly indicates that the $f_{2}, D_{10 \min }$ and $T_{50 \%}$ values are strongly dependent on the selected independent variables. The fitted regression equations relating the responses $\mathrm{f}_{2}, \mathrm{D}_{10 \mathrm{~min}}$ and $\mathrm{T}_{50 \%}$ are shown in the equations, respectively. The equation conveyed the basis to study of the effects of variables. The regression coefficient values are the estimates of the model fitting. The $\mathrm{r}^{2}$ was high indicating the adequate fitting of the quadratic model (Table 13).

\begin{tabular}{|c|c|c|c|}
\hline \multirow{2}{*}{ Independent variables } & \multicolumn{3}{|c|}{ Levels } \\
\cline { 2 - 4 } & Low & Medium & High \\
\hline $\mathrm{X}_{1}=\%$ of CCS & 6 & 7 & 8 \\
\hline $\mathrm{X}_{2}=\%$ of Dried Starch & 9.01 & 10.01 & 11.02 \\
\hline Transformed value & -1 & 0 & 1 \\
\hline
\end{tabular}

Table 4: Design Layout of $3^{2}$ Full Factorial Designs

\begin{tabular}{|c|c|c|c|c|c|c|c|c|c|c|c|}
\hline \multirow{2}{*}{ Batch code } & \multicolumn{2}{|c|}{ Variables } & \multicolumn{9}{|c|}{ Response values } \\
\hline & $\mathrm{X}_{1}$ & $\mathrm{X}_{2}$ & $\mathbf{A}_{20 \text { mins }}$ & $\mathrm{D}_{5 \text { mins }}$ & $\mathrm{D}_{10 \text { mins }}$ & $\mathrm{DE}_{35 \min }(\%)$ & $\mathrm{T}_{25 \%}(\mathrm{~min})$ & $\mathrm{T}_{50 \%}(\mathrm{~min})$ & $\mathrm{T}_{90 \%}(\mathrm{~min})$ & $f_{1}$ & $\mathrm{f}_{2}$ \\
\hline P1 & -1 & -1 & $77.24 \%$ & 50 & 62.32 & 73.66 & 2.65 & 5.0 & 45.0 & 7.3 & 60 \\
\hline $\mathrm{P} 2$ & -1 & 0 & $77.24 \%$ & 52 & 63.58 & 75.88 & 2.50 & 4.25 & 35.0 & 6.3 & 62.8 \\
\hline P3 & -1 & 1 & $77.24 \%$ & 53 & 63.79 & 78.5 & 2.10 & 4.09 & 35.8 & 5.6 & 65.4 \\
\hline P4 & 0 & -1 & $77.24 \%$ & 53 & 64.45 & 80.06 & 1.75 & 4.15 & 25.6 & 6.3 & 65.2 \\
\hline P5 & 0 & 0 & $77.24 \%$ & 55 & 65.87 & 80.98 & 1.65 & 3.70 & 24.0 & 4.8 & 66.3 \\
\hline P6 & 0 & 1 & $77.24 \%$ & 52 & 66.01 & 81.5 & 1.40 & 3.60 & 24.0 & 4.9 & 67.2 \\
\hline P7 & 1 & -1 & $77.24 \%$ & 53 & 65.84 & 82.75 & 1.30 & 3.20 & 23.2 & 3.3 & 73.4 \\
\hline P8 & 1 & 0 & $77.24 \%$ & 54 & 66.67 & 84.667 & 1.20 & 3.10 & 24.0 & 3.4 & 73.5 \\
\hline P9 & 1 & 1 & $77.24 \%$ & 56 & 69.86 & 87.167 & 1.00 & 3.00 & 22.0 & 0.60 & 82.2 \\
\hline FELDENE & & & $77.24 \%$ & 57 & 67.78 & 90.07 & 0.85 & 2.78 & 17.34 & & \\
\hline
\end{tabular}

Table 12: Observed Response from a $3^{2}$ Full Factorial Design 


\begin{tabular}{|c|c|c|c|}
\hline$f_{2}$ & $\mathrm{Y}=65.32+0.82 \mathrm{X}_{1}+2.70 \mathrm{X}_{2}+0.85 \mathrm{X}_{1} \mathrm{X}_{2}+3.32 \mathrm{X}_{1}^{2}+1.37 \mathrm{X}_{2}^{2}$ & $\mathrm{R}=0.9531$ & $\mathrm{p}<0.05$ \\
\hline $\mathrm{T}_{50 \%}$ & $\mathrm{Y}=3.7-0.66 \mathrm{X}_{1}-0.26 \mathrm{X}_{2}+0.20 \mathrm{X}_{1} \mathrm{X}_{2}-0.02 \mathrm{X}_{1}{ }^{2}+0.17 \mathrm{X}_{2}^{2}$ & $\mathrm{R}=0.9320$ & $\mathrm{p}<0.05$ \\
\hline $\mathrm{D}_{10 \mathrm{mins}}$ & $\mathrm{Y}=65.44+2.11 \mathrm{X}_{1}+1.18 \mathrm{X}_{2}+0.64 \mathrm{X}_{1} \mathrm{X}_{2}-0.10 \mathrm{X}_{1}^{2}+0.005 \mathrm{X}_{2}^{2}$ & $\mathrm{R}=0.9963$ & $\mathrm{p}<0.05$ \\
\hline
\end{tabular}

Table 13: Equation of Regression Analysis for Dependent Variables

\section{Batch Selection and Optimization}

The release profile of the reference product, FELDENE, was used for the selection of the ideal values of drug release. The reference product and all the batches satisfied the USP requirement. For final screening, similarity factor $\mathrm{f}_{2}$ was compared for all the batches. The batch with the highest $\mathrm{f}_{2}$ value was selected. Accordingly, batch P9, was ranked as the best batch $\left(\mathrm{f}_{2}=82.2\right)$. The coefficient of Croscarmellose and Dried Starch were nearly the same $(\approx 11)$ indicating favorability of the combination of both excipients. Figure 3 shows the surface response plot of $\mathrm{f}_{2}, \mathrm{D}_{10 \mathrm{mins}}, \mathrm{T}_{50 \%}$ respectively. The plots were drawn using Design Expert software. It is obvious from the figure 3 that by varying concentration of croscarmellose sodium and dried starch one can tailor the selected dependent variable significantly. A multiple response optimization approach was considered more useful and suitable for optimizing the release properties of dosage form. To optimize 2 responses with different targets, a multi-criteria decision approach, like a numerical optimization technique by the desirability function was used to generate the optimum settings for the formulation. The variables were optimized for the response $\mathrm{Y}_{1}-\mathrm{Y}_{3}$ and the optimized experimental parameters were set by targeting the $\mathrm{f}_{2}$ at 95 (Figure 4 ). The $\mathrm{t} 50 \%$ was kept at the range of between 2.6-2.7 and $\mathrm{D}_{10 \mathrm{~min}}$ was kept at the range of between $67 \%$ (Figure 5). Two solutions were found with a desirability of 0.9056 and 0.5259 . The formulation having the highest desirability was composed of $8 \%$ CCS and $10.85 \%$ Dried Starch. The new optimized combinations were prepared according to the predicted model and evaluated for the responses. The results (Table 14) showed a good relationship between the experimented and predicted values, which confirms the practicability and the validity of the model [12].

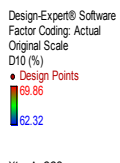

$X_{1}=A: C C S$
Xe: $=:$ : DRED STARCH

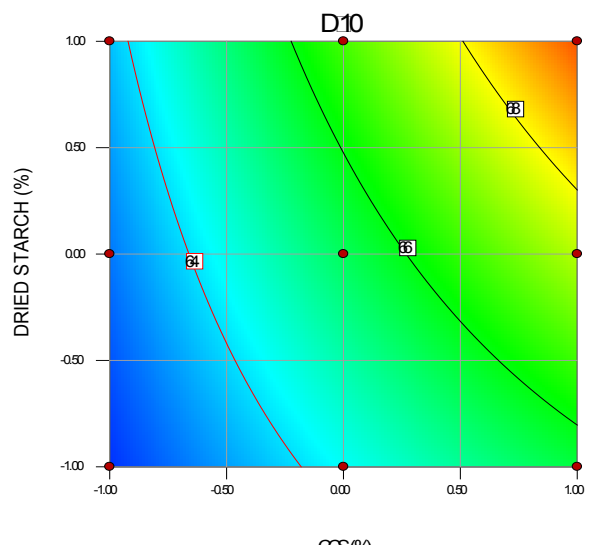

$\cos (\%$

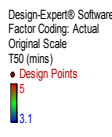

$X 1=A:$ CCS
X2 $=$ B: DRED STARCH

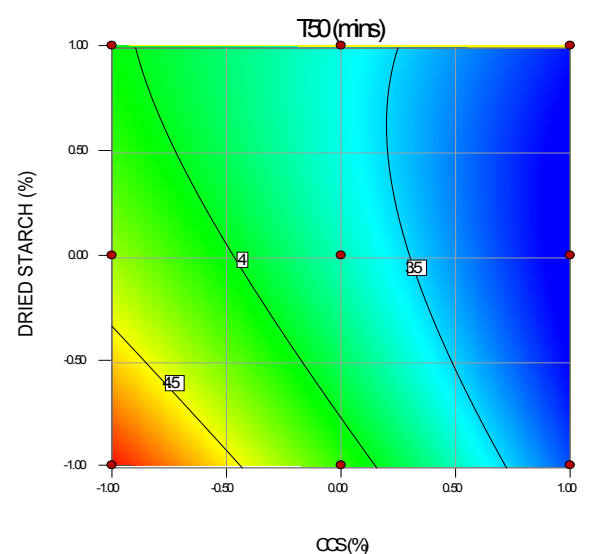

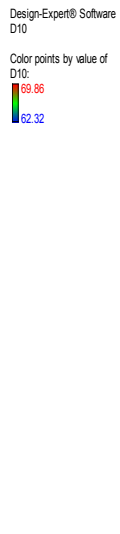

Design-Expente Soltware
T50
Color points by value of
T50:
$\prod_{3.1}^{5}$

Figure 5: Contour plots and PREDICTED vs. Actual graph for $\mathrm{T}_{50 \%}, \mathrm{D}_{10 \mathrm{mins}}$
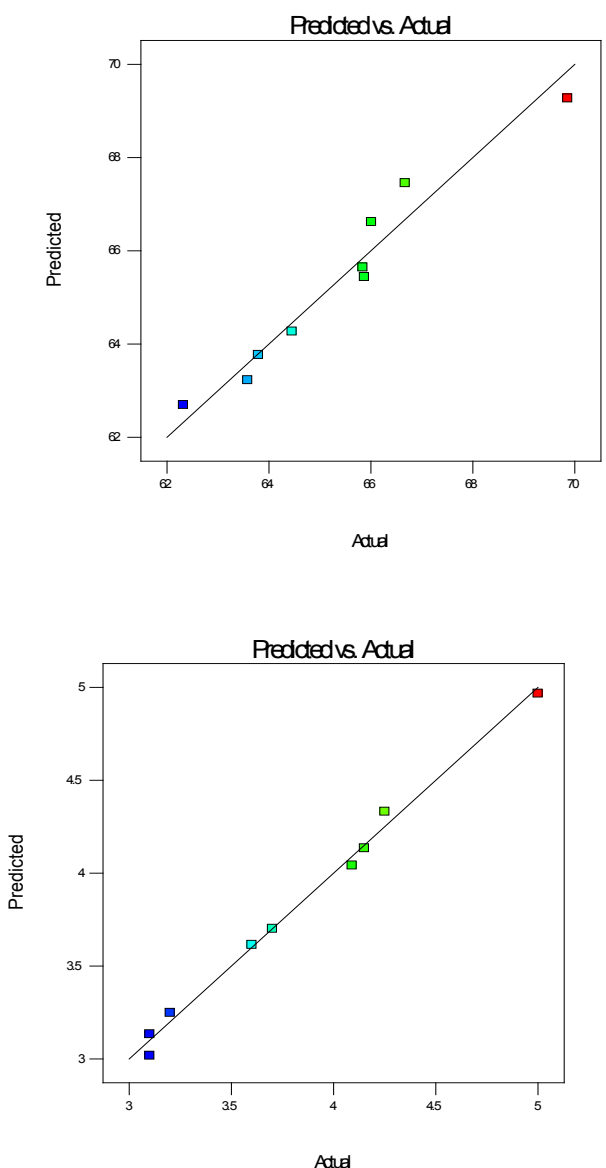

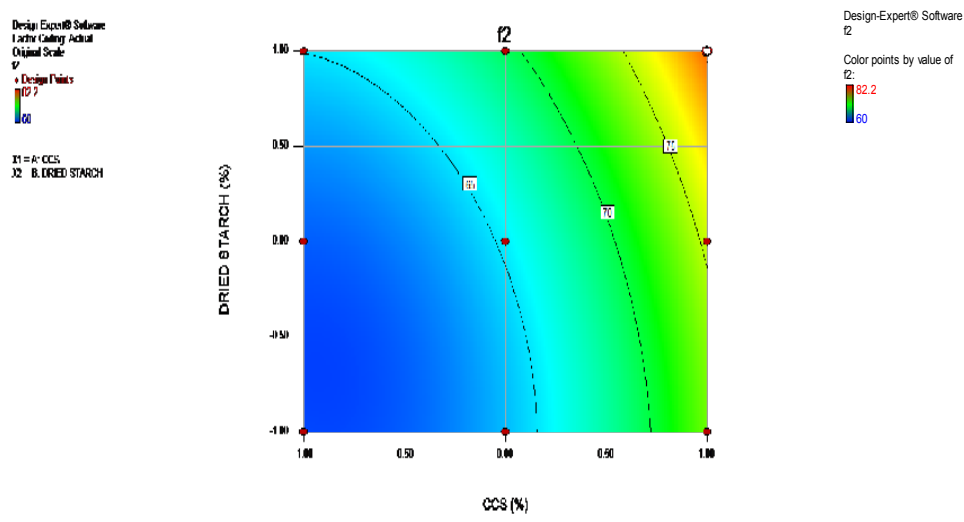

Figure 4: Contour plot and PREDICTED vs. Actual graph for $f_{2}$

\begin{tabular}{|c|c|c|c|c|c|c|}
\hline \multirow{2}{*}{$\begin{array}{c}\text { Optimized } \\
\text { formulation }\end{array}$} & \multicolumn{2}{|c|}{ Composition (\%) } & \multirow{2}{*}{$\begin{array}{c}\text { Dependent } \\
\text { variable }\end{array}$} & Experimental & Predicted & Percentage error \\
\cline { 2 - 3 } & $\mathbf{X}_{1}$ & $\mathbf{X}_{2}$ & & 95.89 & 95.23 & 0.78 \\
\hline \multirow{2}{*}{$\mathrm{G} 1$} & \multirow{2}{*}{8.2} & \multirow{2}{*}{12.4} & $\mathrm{f}_{2}$ & $67.43 \%$ & $67.11 \%$ & 1.34 \\
\cline { 5 - 7 } & & & $\mathrm{D}_{10 \text { min }}$ & 2.89 & 2.75 & 1.28 \\
\hline
\end{tabular}

Table 14: Comparison between the Experimented (E) and Predicted (P) values for the most probable optimal formulations

\section{Conclusion}

Improved formulation factors were systematically studied for the development of immediate release capsules of Piroxicam. It is possible to fabricate immediate release capsules of Piroxicam using Croscarmellose sodium and Dried Starch. The combination of both excipients brings synergistic results. The economy of dried starch may help the formulator to decrease cost of the fabricate product. The initial drug burst release was initiated by quick swelling and wicking of croscarmellose sodium. The capsules had low weight variation and good content uniformity. The capsules passed both USP acceptance criteria. The dissolution profile of the optimized capsules was essentially equivalent to that of the innovator capsules.

\section{References}

1. Simoens S, Coster SD (2006) Sustaining Generic Medicines Markets in Europe. Research Centre for pharmaceutical care and pharmaco - economics.

2. Generics (2013) European generic medicines association. Belgium.

3. Food and Drug Administration (2010) Abbreviated New Drug Application.

4. Food and Drug Administration (2010) Development Approval Process.

5. Singh DP (2010) Generic drug access in global scenario. J Pharm Sci Res 2: 90-8.

6. Physicians Desk Reference 2006 ( $5^{\text {th }}$ edn) Thompson Publisher, 2498-503.

7. Podczeck F, Newton JM (1999) Powder filling into hard gelatine capsule on a tamp filling machine. Int J Pharm 185: $237-54$.

8. Augsburger L (1996) Hard and Soft Shell Capsules Modern Pharmaceutics (3rd Edn) New York, NY, USA, 395- 440.

9. Mohanachandran PS, Sindhumol PG, Kiran TS (2011) Superdisintegrants: an overview. Int J Pharm Sci Rev Res 6: 105-9.

10. Khan KA (1975) The concept of dissolution efficiency. J Pharm Pharmacol 27: 48-9.

11. Moore JW, Flanner HH (1996) Mathematical comparison of dissolution profiles. Pharm Technol 20: 64-74.

12. Bolourtchian N, Hadidi N, Foroutan SM, Shafaghi B (2008) Formulation and optimization of captopril sublingual tablet using d-optimal design. Iranian J Pharm Res 7: 259-67.

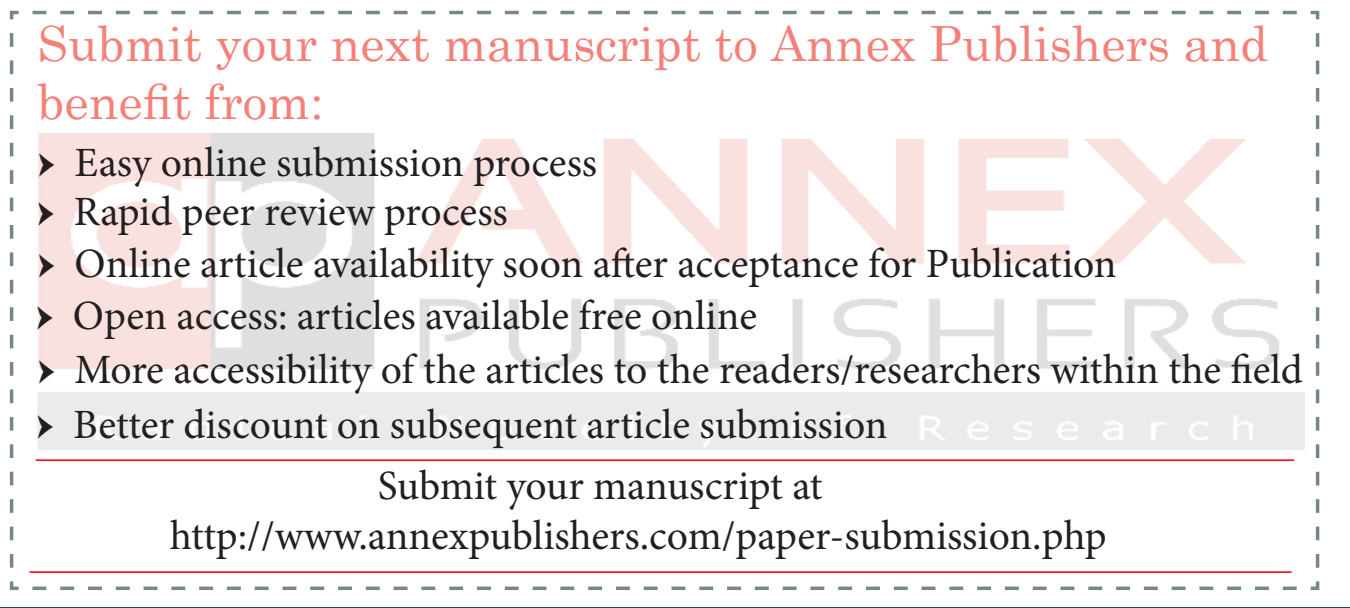

